\title{
Association between Serum Free Thyroxine and Anemia in Euthyroid Adults: A Nationwide Study (Endocrinol Metab 2020;35:106-14, Mijin Kim et al.)
}

Mijin Kim, Bo Hyun Kim

Department of Internal Medicine, Biomedical Research Institute, Pusan National University Hospital, Busan, Korea

We thank Dr. Ma for the careful review and insightful comments regarding our recent publication, titled "Association between serum free thyroxine and anemia in euthyroid adults: a nationwide study" [1]. Although several studies have explored the association between thyroid dysfunction and anemia, data on the association between thyroid function and anemia in the euthyroid range are scarce. In this study, we evaluated the associations of serum free thyroxine ( $\left.\mathrm{fT}_{4}\right)$ and thyrotropin (TSH) with anemia in euthyroid adults. Data collected from a nationally representative cross-sectional survey suggested that a lownormal serum $\mathrm{fT}_{4}$ level was associated with a lower serum hemoglobin concentration and a higher risk of anemia in euthyroid adults, especially in younger adults.

With the increased use of data not originally recorded for research, measurement error is a key challenge to making valid interferences in medical research. We agree with Dr. Ma's comment that repeated measurements can help avoid underestimating the observed relationship between the studied exposure results. However, the possibility of underestimation is presumed to be low because all biochemical parameters measured by the Korea National Health and Nutrition Examination Survey (KNHANES) met the standards of the quality control and assurance program of the College of American Pathologists [2].

As Dr. Ma pointed out, there were differences in the reference

Received: 16 July 2020, Accepted: 23 July 2020

Corresponding author: Bo Hyun Kim

Division of Endocrinology and Metabolism, Department of Internal Medicine,

Biomedical Research Institute, Pusan National University Hospital, 179 Gudeok-ro, Seo-gu, Busan 49241, Korea

Tel: +82-51-240-7678, Fax: +82-51-254-3237, E-mail: pons71@pusan.ac.kr ranges of TSH and $\mathrm{fT}_{4}$ levels according to age and sex [3]. However, the regional differences associated with iodine intake contributed significantly more to differences in the reference intervals of TSH and $\mathrm{fT}_{4}$ than age and sex [3]. The reference interval of serum TSH was 0.45 to $4.12 \mathrm{mIU} / \mathrm{L}$ in the United States and the corresponding value was 0.62 to $6.86 \mathrm{mIU} / \mathrm{L}$ in Korea [2]. In addition, there is evidence that age-related differences in iodine intake affect serum TSH levels [3]. In this regard, we defined a euthyroid state as serum $\mathrm{TSH}$ and $\mathrm{fT}_{4}$ levels within the reference range of the Korean population from the KNHANES VI data, and adjusted for age, sex, and iodine intake.

In accordance with Dr. Ma's comment, determination of the etiology of anemia and an appropriate choice of treatment are important. Iron deficiency anemia, hemolytic anemia, and anemia of chronic disease seem to be associated with thyroid dysfunction [4]. As described in the Discussion section, we did not additionally measure ferritin and transferrin to distinguish between iron deficiency and anemia of chronic disease due to the retrospective design. Further studies are required to determine the association between thyroid dysfunction and the cause of anemia.

Dr. Ma's valuable comments enable a more thorough understanding of our article. We deeply appreciate Dr. Ma's comments, which have enriched our study.

Copyright $\odot 2020$ Korean Endocrine Society

This is an Open Access article distributed under the terms of the Creative Commons Attribution Non-Commercial License (https://creativecommons.org/ licenses/by-nc/4.0/) which permits unrestricted non-commercial use, distribution, and reproduction in any medium, provided the original work is properly cited. 


\section{CONFLICTS OF INTEREST}

No potential conflict of interest relevant to this article was reported.

\section{ORCID}

Mijin Kim https://orcid.org/0000-0002-1538-8859

Bo Hyun Kim https://orcid.org/0000-0001-9632-9457

\section{REFERENCES}

1. Kim M, Kim BH, Lee H, Jang MH, Kim JM, Kim EH, et al. Association between serum free thyroxine and anemia in euthyroid adults: a nationwide study. Endocrinol Metab (Seoul)
2020;35:106-14.

2. Kim WG, Kim WB, Woo G, Kim H, Cho Y, Kim TY, et al. Thyroid stimulating hormone reference range and prevalence of thyroid dysfunction in the Korean population: Korea National Health and Nutrition Examination Survey 2013 to 2015. Endocrinol Metab (Seoul) 2017;32:106-14.

3. Park SY, Kim HI, Oh HK, Kim TH, Jang HW, Chung JH, et al. Age- and gender-specific reference intervals of TSH and free T4 in an iodine-replete area: data from Korean National Health and Nutrition Examination Survey IV (2013-2015). PLoS One 2018;13:e0190738.

4. Soliman AT, De Sanctis V, Yassin M, Wagdy M, Soliman N. Chronic anemia and thyroid function. Acta Biomed 2017; 88:119-27. 